\title{
TWO LEVELS OF HEDONISTIC INFLUENCE ON MICROECONOMIC THEORY
}

\author{
Stavros A. Drakopoulos \\ University of Aberdeen
}

I

\section{INTRODUCTION}

Hedonism is the philosophical view that the maximization of pleasure or happiness is the highest good and aim of life. Hedonism had, and indeed still has, considerable influence on many areas of intellectual activity. ${ }^{1}$ Hedonistic ideas were first introduced into economics with the work of Bentham and influenced the members of the late classical school, especially J. S. Mill and W. N. Senior. The peak, however, of hedonistic influence on economics was reached in the marginalist period. The works of Jevons and Edgeworth, for instance, were explicitly based on the hedonistic idea of selfish maximization of pleasure or utility. The hedonistic influence during that time became explicit and an important manifestation of its strength was that the main feature of the economic agent was the selfish maximization of utility. The influence of the Benthamite spirit on the late classical school and on the marginalist school has been recognized by a number of theorists such as T. Veblen, J. M. Keynes and A. W. Coats (see Veblen, 1972 [1906], Keynes, 1973 [1933], and Coats, 1976).

At the beginning of this century a tendency to diminish the hedonistic orientation of orthodox economic theory appeared. The principal reasons for this were, on the one hand, the movement towards a neutral economic science freed from psychological assumptions (inspired by the spirit of logical positivism) and, on the other, the heterodox attack on the hedonistic basis of mainstream theory. This started with the work of Pareto and Fisher and became stronger with the work of Robbins, Hicks and Samuelson. The notions of utility and satisfaction and the conception of the consumer as a satisfaction maximizer were replaced by the Hicksian theory of consumer choice and Samelson's

${ }^{1}$ The origins of hedonism can be found in the writings of ancient Greeks and especially in Aristipus and Epicurus (see Zeller, 1901, p. 123, and Diogenes Laertius, 1975, [c. A.D. 230] Book 5). For a discussion of different versions of hedonism (psychological, philosophical), see Frankena, 1963, pp. 67-72.

This paper has benefited from comments from Brian Loasby, Sheila Dow, Ron Shone and from an anonymous referee. The usual disclaimer applies.

Date of receipt of final manuscript: 30 October 1989 . 
revealed preference theory. Nowadays the majority of theorists follow the line that large bodies of economic theory (especially microeconomic theory) are independent of any philosophical or psychological basis like hedonism.

Despite the move towards a positive science of economics, however, if one looks at contemporary economic textbooks one will find both explicit and implicit indications of the hedonistic approach. The influence of hedonism is such that one can safely say that textbook consumer behaviour theory is closer to the makers of the marginalist revolution, and that the attempts made in recent decades to construct a value-free economic science have had a minimal impact on economic textbooks.

A number of explanations can be offered for the discrepancy between modern consumer theory and textbook consumer theory. My contention is that this discrepancy is due to the necessity of the framework of egoistic hedonism for the comprehension of consumer theory; and this may in turn imply that, despite the attempts of Hicks and Samuelson, hedonism is still one of its important underlying characteristics. This explanation can also be supported by indications of hedonistic influence in recent economic literature.

In short, the purpose of this paper will be to show the two levels of hedonistic influence on economic theory (especially consumer behaviour theory), and then to try to offer an explanation for this phenomenon.

\section{Hedonistic Influence on the Marginalist SchoOl}

As some historians of economic thought have realized (but not adequately emphasized), the systematic introduction of hedonistic ideas in economics took place in the first decades of the nineteenth century with the work of J. Bentham (see Schumpeter, 1963, pp. 66, 887-8; Roll, 1961, pp. 378-85; and Blaug, 1978, pp. 379-88). Bentham was responsible for the introduction of many hedonism-based ideas and terms in economics, such as the very concept of utility and the basic objective of economic agents: utility maximization (Bentham, 1823, pp. 1-2).

J. S. Mill, W. N. Senior and other members of the late classical school elaborated further Bentham's hedonistic views (see Mill, 1979 [1863] and Senior, 1850). However, the peak of the hedonistic influence on economics was reached with the emergence of the marginalist school. The emphasis on questions of allocation which was a basic feature of marginalist thought meant that a model of standard economic behaviour was needed. In addition, the emergence of marginalism signified a shift from the supply-based explanation of value and prices to a demand-based explanation. The attempt to analyse the concept of demand assisted the application of hedonistic ideas. Moreover, the increasing tendency towards a formalistic methodology required a well-defined economic agent with standard and predictable behaviour. The hedonistic framework was the ideal, and thus the marginalist period marked the height of hedonistic influ- 
ence on economic theory. The evidence of hedonistic influence (especially egoistic hedonism) ranges from a hedonistically based definition of economics to an explicitly hedonist economic agent (see Jevons, 1871, pp. 32, 44; Menger, 1950 [1871], p. 123; Menger, 1963 [1883], p. 87; Walras, 1965 [1874], pp. 121, 125; Jaffé, 1977, p. 305; Edgeworth, 1881, pp. 15, 16).

\section{THE EMERGENCE OF ANTI-PSYCHOLOGISM}

Around the turn of the century a number of economists started to worry about the profoundly hedonistic image of economic theory and there was a movement to minimize that image. One reason for this movement may have been the increasing influence of positivist methodology which called for a social science without psychological elements. This was reinforced by the heterodox critique (see, for instance, Veblen, 1972 [1906], p. 178) of the psychological content of hedonism.

Essentially, this movement led to the work of Robbins, who established the methological justification for minimizing the hedonistic image and continued with the work of Hicks and Samuelson. However, the first steps in this direction were made by Pareto, who was motivated in this attempt by the same reasons as subsequent economists (see Drakopoulos, 1989). He thought that social sciences should follow the logico-experimental method by which they would be able to discard all the metaphysical abstractions (see also Aron, 1967, p. 45). Pareto is viewed by the majority of economists as having started the process of establishing a positive economic science and as the originator of ordinal utility (see Roll, 1961, p. 409; Blaug, 1980, pp. 140, 141; Whittaker, 1960 , pp. 301, 302). His use of index numbers, his attempt to avoid value-laden terms like utility or pleasure, and his endeavour not to use the concept of economic man, were in the spirit of subsequent developments. Despite this, however, Pareto cannot help going back to familiar marginalist notions like a reference to economic man, pleasure and the utility hill, in the section concerning the construction of indifference curves (Pareto, 1971 [1908], p. 120).

In the same spirit, I. Fisher tried to replace all previous psychological assumptions of economics with a 'simple psycho-economic postulate: each individual acts as he desires' (Fisher, 1965 [1892], p. 11). Like Pareto, however, Fisher could not help going back to notions like maximum satisfaction when, for instance, he discussed the relationship between price, quantity and marginal utility (Fisher, 1965 [1892], pp. 25, 26).

\section{Robbins}

Although Pareto started the downplay of hedonism in economics, Robbins provided the methodological justification and thus set the basis for the construction of an apparently value-free economic science. Robbins attempted to 
do in economics the same thing that others were doing in the social sciences. (Behaviourist psychologists, for instance, attempted to reject conscience from psychology in order to build a positive, scientific psychology; see Watson, 1930). Robbins was also aware of the attacks of non-orthodox economists on the psychological assumptions of economics (Robbins, 1932, p. 84). However, he emphasized that these assumptions were not a fundamental part of the theory, thus implying that economic theory could be built without these subjective notions (Robbins, 1932, pp. 85, 86).

His new definition of economics was in the same spirit, stressing that economics is a study of the relationship between ends and means (not of the ends and means themselves). Thus the study of ends is beyond the scope of economics. (Robbins, 1932, p. 15). This was the first step towards an apparently psychology-free economic science. Furthermore, Robbins realized that the idea of a psychology-free economic science was incompatible with the existence of the concept of economic man which was based on psychological assumptions. Thus he attempted to minimize its importance by stating: 'it is only an expository device-a first approximation used very cautiously at one stage in the development of arguments which, in their full development, neither employ any such assumption nor demand it in any way for a justification of their procedure' (Robbins, 1932, pp. 85, 86).

The attempt to redefine the concept of utility was another part of the antipsychologist movement. In a subsequent book, Robbins attempted to expel any hedonistic connotation from the concept. He pointed out that utility is not utility in the sense of psychological hedonism, but rather a neutral quality of being the object of desire-hedonist or otherwise (Robbins, 1970, p. 27).

Robbins provided the methodological justification of a value-free, positive economic science, and therefore assisted the development of an economic theory apparently independent of hedonism.

\section{Hicks}

A few years after the appearance of Robbins's main methodological work, John Hicks published his Value and Capital (although other economists had made similar attempts earlier on-Slutsky, 1915; Johnson, 1913; Hicks and Allen, 1934-Hicks's work was by far the most influential). The underlying characteristic of this work was the rejection of basic marginalist concepts such as utility, as being 'psychologically biased', and the introduction of a new 'objective' approach. (The replacement of the cardinal approach of the marginalists with the ordinal approach can be seen in the same context.) Hicks thought that the subjective, utilitarian-hedonistic approach of marginalist economists did not constitute a legitimate scientific method. Thus his basic effort was the replacement of marginalist utility theory with an objective, positive theory of choice. As one would expect, the introduction of a neutral theory of choice tended to minimize the hedonistic image of microeconomics. Hicks's intentions can be seen on the first page of his book, when he writes: 'If one is utilitarian in philosophy, one has a perfect right to be utilitarian in one's economics. But 
if one is not (and few people are utilitarians nowadays) one has the right to an economics free of utilitarian assumptions' (Hicks, 1946 [1936], p. 18).

Hicks, then, undertook a purge in order to eliminate all the hedonistic elements from economic theory. His first target was the very notion of utility. In the place of 'marginal utility' Hicks put the new concept of 'marginal rate of substitution', defining 'the marginal rate of substitution of $\mathrm{X}$ for $\mathrm{Y}$ as the quantity of $\mathrm{X}$ which would compensate the consumer for the loss of a marginal unit of Y'. (Hicks, 1946 [1936], p. 20). The concept of 'diminishing marginal utility' was replaced by that of 'diminishing marginal rate of substitution'. Hicks also constructed indifference curves in a different way, attempting to perfect Pareto's idea of constructing an indifference curve without using subjective concepts. He conceived of indifference curves as showing the combination of goods for which the individual is indifferent. They portray preferences and that is why sometimes they are called preference-based indifference curves. (The basic difference between Hicksian and Paretian indifference curves is that in Hicks's a commodity space is used instead of a utility hill.) It has to be noticed, however, that the explanation of lower and higher indifference curves again involves the notion of utility level.

\section{Samuelson}

Samuelson, like Pareto, Robbins and Hicks, believed that economics could acquire the scientific prestige of the positive sciences if it could free itself from 'subjective' elements. The other motive for the construction of his theory was the critique of the hedonistic or utilitarian bias of orthodox economics by heterodox economists. In his most important work, he emphasized the nonhedonistic nature of modern theory in contrast to the marginalist one. 'Concomitantly, there has been a shift in emphasis away from the physiological and psychological hedonistic, introspective aspects of utility ... At the same time there has been a similar movement away from the concept of utility as a sensation, as an introspective magnitude' (Samuelson, 1947, pp. 61, 62).

Samuelson, however, was not perfectly happy with the state of modern consumer theory. In an earlier article, he expressed the belief that even Hicks's analysis was not entirely free of traces of the utility concept (Samuelson, 1938, p. 61). The essence of Samuelson's argument was that in Hicksian analysis the preference function (indifference curve) is implicitly assumed. In the same article he went on to set the basis for a complete 'positive' consumer behaviour theory. This theory, Revealed Preference, (RPT) was allegedly based on observed behaviour only. Influenced by the behaviourist psychology which emphasized observed behaviour and neglected the underlying motivations, Samuelson tried to get away from the 'subjective' concepts by accepting observed behaviour alone. His starting point was that the individual behaves as he behaves. However, for the construction of RPT the above point is not enough; three axioms are also needed. The most important of these is the transitivity axiom, stating that the individual will be consistent in the following 
sense: It will never be the case that both

$$
\left(\mathrm{x}^{\prime}\right)<(\mathrm{x})
$$

and

$$
\text { (x) }<\left(\mathrm{x}^{\prime}\right)
$$

where $(x)$ and $\left(x^{\prime}\right)$ are bundles of goods (see Samuelson, 1938, pp. 61-5.)

The transitivity axiom is also known as the weak axiom, which Samuelson-with the assistance of $\mathrm{H}$. Houthakker-was to substitute with the strong axiom (stronger transitivity) some years later (see Samuelson, 1950, pp. 335-85, and Houthakker, 1950, pp. 159-74). Samuelson constructed the familiar notion of an indifference curve from his RPT, allegedly without using psychological (hedonistic) terms. He was concerned to note that his theory did not need the concept of economic man or the notion of utility. After Samuelson, subsequent economists worked on the construction of a general choice theory free from any psychological connotations (Arrow and Debreu are the first examples that come to mind; see, for instance, Arrow and Debreu, 1954, and Debreu, 1959). In contemporary theoretical discussions, the 'neutrality' conception of choice theory is reinforced by the notion of rationality. In the neo-classical framework, the behaviour of the consumer is considered rational when it conforms to the axioms of the theory of choice.

Thus, by the 1950s, the vast majority of theorists believed that microeconomic theory in general and consumer theory in particular was a neutral theory without value-laden concepts. The works of a number of economists, but mainly of Pareto, Robbins, Hicks and Samuelson, were responsible for this. These economists did not invent a new theory but suggested that the same principles can be constructed without psychological assumptions. Robbins provided the methodological framework; Hicks extended Pareto's approach and constructed a choice theory; and finally, Samuelson attempted to remove any trace of hedonism from economic theory by suggesting his observation-based theory. In my view the success of these attempts to expel hedonism from microeconomic theory is questionable. However, the important point here is that most economists thought that there was a paradigm shift from a hedonistic-based theory to a positive, scientific theory. The influence, then, of hedonism, at least on the surface, was minimal.

\section{IV}

\section{HEDONISM AND ECONOMIC TEXTBOOKS}

One can argue that textbooks reflect theoretical developments, with a possible time lag of some years. This was the case with the new, revolutionary (in comparison to the classicals) Keynesian ideas which became part of the accepted body of knowledge and subsequently of textbook material as early as in the beginning of the 1950s (see, for instance, Cairncross, 1955, pp. 505-77). 
The crucial developments in microeconomic theory discussed in the previous section became part of the accepted body of knowledge of orthodox economics in the 1940s and 1950s. However, if one looks at contemporary influential economic textbooks, one will find that the marginalist approach constitutes the core of consumer theory or production theory, three or four decades after Hicks's and Samuelson's attempts. The majority of textbooks use the terms utility and satisfaction or pleasure as synonymous. This happens in elementary textbooks such as McConnell, 1975, p. 488; Begg et al., 1984, p. 90; and Graven, 1984, pp. 168-9); the same thing can also be observed in more advanced texts. For instance, one can read in Henderson and Quandt:

If we have a utility function of the form

$$
\mathrm{U}^{0}=f\left(q_{1}, q_{2}\right)
$$

then since the utility function is continuous (1) is satisfied by an infinite number of combinations of $q_{1}$ and $q_{2}$. Imagine that the consumer derives a given level of satisfaction $U^{0}$ from 5 units of $q_{1}$ and 3 units of $q_{2}$. (Henderson and Quandt, 1980, p. 9)

Another intermediate textbook follows the same approach. Ferguson and Gould write: 'A consuming unit-either an individual or a household-derives satisfaction or utility from the services provided by the commodities consumed during a given time period' (Ferguson and Gould, 1975, p. 12). Other widely used intermediate (and sometimes advanced) texts follow the same approach (see, for instance, Koutsoyiannis, 1979, p. 18). It is clear that these works are much closer to the marginalist line of thought than to developments of more recent decades.

Apart from identifying utility with satisfaction as the marginalists did, many contemporary textbooks explicitly refer to the concept of economic man. In spite of Robbins's efforts to minimize its importance, the concept can be found in a number of textbooks, and is almost identical to that of the preRobbinsonian era. L. Friedman states: 'The model of economic man can be described in terms of four assumptions ... These assumptions form a model of decision making sometimes referred to as economic man, where each individual is portrayed as a utility maximizer' (Friedman, 1985, pp. 22, 23). Although it is not usually stated explicitly, economic man is often viewed as selfish. Thus, although few authors would explicitly adopt egoistic agents, the stereotype is that the satisfaction of the individual depends on what he consumes and nothing else (see also Winter, 1969, p. 9). The model of economic man is present in D. Laidler's text when he writes: 'The consumer wishes to do as well as he can for himself, to select that consumption pattern out of those available to him that will yield the highest possible level of satisfaction-he wishes to maximize his utility' (Laidler, 1981, p. 15). The attempt by orthodox theorists to reduce all characteristics of economic man into one-rationality-is not very popular among textbook writers, who still conceive him explicitly as a satisfaction maximizer.

As one would expect from the above, the notion of the indifference curve is 
not explained in Hicksian terms but in marginalist terms: 'The locus of all commodity combinations from which the consumer derives the same level of satisfaction forms an indifference curve. An indifference map is a collection of indifference curves corresponding to different levels of satisfactions' (Henderson and Quandt, 1980, p. 9). Exactly the same definition is given by Koutsoyiannis $(1979$, p. 18). The Hicksian notion of a 'neutral' indifference curve or map seems to have little impact on contemporary textbooks. (As observed above, Hicks avoided mentioning any subjective concept like 'satisfaction' in his discussion of the indifference map.)

In addition, the analysis of consumer equilibrium that can be found in the majority of texts is conducted in terms of satisfaction or utility levels. The consumer is viewed as having a given budget constraint which is represented by a straight line or a linear equation. The maximum of consumer satisfaction or utility is attained at the point of tendency of the budget line with the highest indifference curve (maximization of a utility function). Many textbooks follow this approach without worrying too much about using concepts which were used by the marginalists years ago (see, for instance, Laidler, 1981, p. 14; Miller, 1978, p. 31).

There are cases, however, where the modern developments are taken into account (this is the case among more advanced texts). The Hicksian term 'marginal rate of substitution' (which was meant to replace the hedonistic 'marginal utility') is mentioned by many texts. However, the term is connected with the notions of satisfaction or utility which it was originally meant to replace. In an intermediate text one can read: "[The marginal rate of substitution of $x$ for $y$ is] the number of units of $y$ that must be given up per unit of $x$ gained if the consumer is to either feel equally well-off or to continue to obtain the same level of satisfaction' (Miller, 1978, p. 21). Exactly the same line of explanation is followed by Ferguson and Gould, and Koutsoyiannis, where the concept of constant level of satisfaction is used to explain compensation (Ferguson and Gould, 1975, p. 24; Koutsoyiannis, 1979, p. 18).

Few texts refer to Samuelson's revealed preference theory as a theory which was intended to replace the value-laden marginalist utility theory. In many cases RPT is mentioned only in a brief footnote (see, for instance, Miller, 1978, p. 31) or as a way of explaining index numbers. Generally, textbooks connect modern choice theories with marginalist analysis without giving a hint that the purpose of those theories was to free economics from the psychological assumptions of the marginalists. An example of such a textbook is Lancaster's, where one can read:

Since 'most preferred' and 'giving greatest utility' are synonymous, we can make an addition to the list of equivalents to the statement that the consumer chooses point $C$ on his budget line: At point $C$, the consumer maximizes his utility for points on the budget line ... The decision to use utility analysis or direct preference analysis is simply a matter of convenience. (Lancaster, 1974, pp. 321-32)

The same line is followed by Stonier and Hague who discuss revealed pre- 
ference by mentioning that the underlying assumption of the theory is a satisfaction-maximizing consumer (Stonier and Hague, 1980, p. 91).

In addition, some textbooks define economics along the old marginalist lines (economics is defined as a calculus of pleasure and pain). It seems that Robbins's apparently value-free definition had little influence on them. It must be noted that such definitions are rare in textbooks; what this shows, however, is that the explicit influence of hedonism-orientated marginalist economists is still present even in so a basic thing as the definition of economics (see for instance, Solmon, 1976, p. 14).

The above examples demonstrate that the influence of the hedonistic framework on many textbooks is considerable. Important sections of microeconomic theory are presented in a way that is explicitly based on hedonistic ideas. Thus, although economists such as Pareto, Robbins, Hicks and Samelson thought that they had freed economics from psychological (hedonistic) influence, contemporary textbooks indicate otherwise. At this point it has to be mentioned that Hicks and Samuelson considered their theories revolutionary in comparison to the old subjective, marginal utility theory. Although it can be maintained that the introduction of Keynesian ideas had a greater significance because it clearly disputed the old theories, one cannot help drawing parallels with the introduction of the allegedly psychology-free theory of choice. In spite of this, the textbooks did not take into account the full significance and change in terminology as they did with the Keynesian ideas.

V

\section{Possible Explanations}

A number of possible explanations can be suggested for the above discrepancy. The first cites pedagogic reasons. In particular, it can be argued that textbook writers attempt to simplify theory in order to make it easier for students. Thus it is better to use concepts which are easier. In the same context, one can also argue that Marshall's usage of utility and utility maximization has exercized an important influence on the teaching of economics and therefore on textbooks.

Another explanation could be that according to a widespread methodological belief, the validity of the assumptions is not important for the construction of economic theories. Thus, it does not really matter if the assumptions of textbooks are based on hedonistic ideas.

A third explanation might be the following: the framework of psychological hedonism is necessary for the comprehension of orthodox consumer theory: thus, despite Hicks's and Samuelson's attempts, hedonism is still an important underlying characteristic. In particular, the explicit hedonistic influence on textbooks can be seen as a reflection of the criticisms of the alleged neutrality of the modern theories of choice by various theorists such as N. GeorgescuRoegen, J. Robinson, E. J. Mishan, W. Kroebel-Rier, B. Loasby, S. Wong and 
L. Bolland. I tend to believe that the last explanation is more plausible than the first two.

\section{First explanation: pedagogic reasons}

It can be maintained that simplification purposes are responsible for the presence in textbooks of hedonistic concepts. An initial observation which undermines this explanation is that, as we saw, hedonistic concepts are not used only in introductory textbooks, but also in intermediate ones. One can even find examples of advanced texts where utility theory is explicitly considered as 'a more powerful tool' than choice theory (see, for instance, Green, 1976, p. 80). This is a first indication that hedonistic ideas are not used for simplification purposes.

Another argument which supports this is the existence of few elementary textbooks where consumer theory is presented solely in terms of a general choice theory. An example of such a textbook is V. Walsh's Introduction to Contemporary Microeconomics. Walsh's textbook starts with a brief reference to the history of the utility concept and its subsequent replacement. After presenting the main points of consumer theory according to Jevons, Marshall and Edgeworth, Walsh goes on to emphasize that this theory has been replaced by a theory of choice. The whole subsequent analysis is based on Hicks's approach. In contrast to many texts, Walsh discusses indifference curves in terms of preferences not in terms of utility (see Walsh, 1970). The fact that the text has been a popular student textbook for many years indicates that choice theory can be presented simply enough to be understood by first-year university students. Further argument against the simplification hypothesis is that the great majority of writers explicitly advocate a positivist economic methodology. This implies that value-laden terms are not permitted (even if they can simplify theories) for methodological reasons (see, for instance, Lipsey, 1984).

Apart from simplicity one can suggest another explanation at the pedagogic level which has to do with Marshall's influence. It can be argued that Marshall's analysis of consumer behaviour and demand in terms of utility and utility or pleasure maximization has had an important effect on the way that economics is taught (see Marshall, 1961 [1890], p. 838). In Marshall's work one can find the main elements of a utility-based consumer theory. A note of caution is necessary before we proceed: it should be mentioned that the contemporary textbook representation of Marshall's work is partial. Marshall was always very careful about utility analysis. First of all, most parts of his work which can be identified in modern texts were only mentioned in appendices, and he was always anxious to emphasize that they belong to Hedonics but not to economics (Marshall, 1961 [1890], p. 841). It is clear that he put much less emphasis on utility analysis than other contemporary theorists. Furthermore, as an indication of his unique approach, the Marshallian theory of value, unlike that of other marginal utility theorists, was a combination of marginal utility and costs of production (see Loasby, 1978, p. 2). These facts imply that the hedonistic dimension of Marshall's thought has been overemphasized 
by textbooks while other parts of his work have been completely neglected (see also Birch, 1985, p. 195). This again indicates the hedonistic bias of contemporary texts.

Although the (distorted) Marshallian influence hypothesis is relevant to a number of textbooks, it is still not adequate to explain fully the abovementioned discrepancy. Examples of texts which adopt a historical approach to the discussion of consumer theory provide evidence for this. In particular, some textbooks present Marshall's theory first and then the indifference analysis specifying their differences and their historical context, but still explain choice theory in terms of satisfaction maximization. Thus textbook writers who are conscious of the Marshallian tradition but also of its differences from choice theory feel the need to explain modern choice theories by refering to hedonistic related concepts. The case of Koutsoyiannis is indicative: there is a reference to Marshall when cardinal utility theory is discussed and references to Hicks and Samuelson when indifference and revealed preferences are presented. Still, however, indifference and preference are explained by using the concept of utility or satisfaction (see Koutsoyiannis, 1979, pp. 14-32; also Bilas, 1967, pp. 55-82).

\section{Second explanation: Friedman's thesis}

Milton Friedman's 'irrelevance of assumptions thesis' can be viewed as a second explanation of the discrepancy. More specifically, in his Essays in Positive Economics published in 1953, Friedman suggests that the validity of a theory does not depend on the realism of its assumptions, but on the predictions that it yields: also, that it is a positive advantage if the assumptions are unrealistic (see Friedman, 1953, pp. 8, 14). One could justify the use of hedonism-orientated assumptions by textbook authors in terms of this methodological position. Although a number of theorists have reacted against Friedman's thesis (e.g. Samuelson, Koopmans, Rotwein), it can be maintained that it had a significant influence on economic methodology (see Samuelson, 1963; Koopmans, 1957, and Rotwein, 1959). However, none of the textbooks mentioned explicitly adopts Friedman's methodological ideas (only Miller's text and Ferguson and Gould's are sympathetic to the idea that assumptions are not important for theories). On the contrary, there are examples of texts which refer to the necessity of realistic assumptions. One of these texts is that of Stonier and Hague, who state that the ideal would be to device assumptions which come closest to reality (Stonier and Hague, 1980, p. 678). Other authors explicitly call for realistic assumptions or reject Friedman's idea that unrealistic assumptions are a positive advantage for a theory (see Graven, 1984, p. 10 and Koutsoyiannis, 1979, p. 4). In addition, Samuelson's influential textook, which explains consumer theory in hedonistic terms, but denies Friedman's thesis (given Samuelson's methodological position), is another example (Samuelson, 1980, p. 408). 


\section{Third explanation: implicit psychology}

The explicit use of hedonism-based concepts might indicate that psychological assumptions are still implicitly present in modern choice theories, especially when seen in connection with the body of criticisms of these theories. Many textbook authors clearly feel that the students will better comprehend consumer theory if they mention things like "each individual tries to maximize his satisfaction', 'utility means satisfaction' or 'higher indifference curve means higher satisfaction level'. This may indicate that essentially choice theories presuppose the same hedonistic psychology as the marginalist theories did. Even in Walsh's textbook, hedonistic examples are used when choice theory is presented. The above point can be connected with a variety of other criticisms of the modern theory of choice.

In particular, N. Georgescu-Roegen, J. Robinson and S. Wong have pointed out the dependence of RPT on an implicitly assumed utility function. This weakens to a great degree the claim that RPT is 'entirely free of the utility concept' (see Georgescu-Roegen, 1966, pp. 217-27; Georgescu-Rogen, 1976, p. 337; Robinson, 1962, pp. 50-1; Wong, 1978, pp. 59, 73). W. Kroeber-Riel has indicated that RPT still presupposes an economic agent with specific psychological characteristics (Kroeber-Riel, 1971, pp. 340-4). E. J. Mishan and B. Loasby have maintained that modern choice theories in general and Hicksian theory in particular are better understood or 'make sense' if utility and utility maximization are assumed (Mishan, 1961, p. 2; Loasby, 1976, p. 23). Finally, L. Boland has demonstrated that one of the foundations of choice theories, the maximization hypothesis, is basically a metaphysical hypothesis (Boland, 1981, pp. 1032-5). In essence all these arguments point to the fact that modern choice theories are not 'neutral' or independent from all psychological assumptions.

The implicit existence of psychological assumptions supports the view that the explanation of the explicit hedonistic influence on textbooks is the implicit presence of psychological hedonism within the very theories of choice. This thesis can also be supported by a more detailed discussion of the Hicksian and Samuelsonian choice theories as they were presented by Hicks and Samuelson themselves.

First of all, although Hicks and Allen defined indifference curves in terms of preferences (thus attempting to avoid the concept of utility), the notion of satisfaction has to be used when the real reason behind preferences is examined and also when the difference between a lower and a higher indifference curve is discussed. In addition to this, Hicks in his Value and Capital is forced in a way to adopt a few (implicit) psychological assumptions. For instance, after introducing the continuity assumption for the condition of the diminishing marginal rate of substitution, Hicks states 'that the consumer will always prefer a larger amount of $M$ to a smaller amount of $M$, provided that the amount of $X$ at his disposal is unchanged' (Hicks, 1946 [1939], p. 42). This is psychological characteristic of the economic agent which Hicks calls 'the ideal consumer'. In one of his subsequent works, the assumption of a utility-maximizing agent, 
implicitly present in the above passage, is mentioned explicitly (see Hicks, 1956, p. 5). Furthermore, the conception of a selfish, satisfaction-maximizing consumer is explicitly present in Value and Capital itself, (see Hicks, 1946 [1939], p. 55).

The presence of (hedonistic) psychological assumptions in Hicksian choice theory has also been identified by a number of theorists (e.g. E. J. Mishan and B. Loasby). Loasby, for instance, in his Choice, Complexity and Ignorance, points out: 'Preference functions do not logically require the old-fashioned concept of utility; but it is much easier to believe in them if one is allowed to believe in utility as well' (Loasby, 1976, p. 23). One can conclude that despite Hicks's attempt to create a neutral theory, psychological assumptions have not been eliminated.

As mentioned above, the prime objective of Samuelson's RPT was the construction of 'observational' indifference curves, without using subjective concepts such as (utility). Samuelson emphasized that his theory did not require the existence of 'any intensive magnitude which the consumer feels or consults'. However, in the process of his analysis he states:

If this cost [the cost of the second batch of goods] is equal to or less than the amount of money that the first batch actually cost, we have conclusive evidence that the second batch is not higher on the individual's preference scale than the first batch; for if it were, the individual could not have been in equilibrium in the first place, since he would not be minimizing total expenditure for the attained level of satisfaction. (Samuelson, 1947, p. 109)

The use of the concept of satisfaction is in sharp contrast with his previous statement of the non-existence of magnitude that the consumer feels or consults. The previous quotation is not very far from Samuelson's discussion of consumer theory in his Principles: 'As a customer you will buy a good because you feel it gives you satisfaction or utility' (Samuelson, 1980, pp. 408-9). Given his aims of purifying economic theory of subjective elements, one would expect that his treatment of consumer theory would be orientated towards this aim even in an elementary textbook.

Some theorists have criticized the very basis of RPT as an 'observational' theory. Kroeber-Riel, for instance, thinks of RPT as a good example of an 'asif-language'. (In these languages analytical sentences or definitions are used as if they were synthetic and factual-normative theoretical constructs are used as if they were empirical concepts.) According to Kroeber-Riel, in RPT 'observed behaviour is usually understood in an empirical sense although it is a pure theoretical construct' (Kroeber-Riel, 1971, pp. 340-4). Other theorists have demonstrated that RPT is susceptible to serious criticism within its own framework. More analytically, Georgescu-Roegen has shown that the 'weak axiom' of RPT is not sufficient for the construction of indifference curves (GeorgescuRoegen, 1936, pp. 539-49). This led Samuelson (with the assistance of Houthakker) to the extension of the weak axiom to the strong axiom, which 
states that:

$$
\begin{aligned}
\text { if }(x) & >\left(x^{\prime}\right) \\
\text { and }\left(x^{\prime}\right) & >\left(x^{\prime \prime}\right) \\
\text { then }(x) & >\left(x^{\prime \prime}\right) .
\end{aligned}
$$

Even so, according to Georgescu-Roegen the strong axiom does not guarantee that the derived indifference curves would give comparable (at all points) combination of goods (see Georgescu-Roegen, 1966, pp. 217-27). This argument suggests that in RPT, the existence of a regular indifference map is implicitly presupposed, otherwise the theory is problematic. This indicates that RPT belongs to the same conceptual framework as the previous marginalist theories. The same line of argument is followed by Wong, who emphatically states that RPT does not represent a break with the tradition of psychologically based theories of consumer behaviour: 'Consequently, the attendant philosophical and psychological controversies of the utility theory, which Samuelson hopes to erode with his observational theory, are not exorcised from the corpus of economy theory ...' (Wong, 1978, p. 73).

These arguments cast doubt on the view that RPT is a psychology-free theory, and this implies that the third explanation of the recognition lag in textbook material, is the most plausible one. The idea that RPT is not value-free has gained substantial ground in the last years and this can be seen from the textbook approach. In particular, Lipsey's substitution of indifference preference for RPT in the fifth edition of his text is an indication of the growing concern about RPT (see Lipsey, 5th edn, 1979, p. xix).

The discussion so far suggests that choice theories are not psychology-free and thus supports the third explanation about the presence of hedonistic concepts in textbooks. This argument can also be supported by a discussion of recent literature which indicates the preoccupation of modern microeconomics with utility maximization and other hedonism-related concepts.

\section{RECENT EVIDENCE}

A brief review of the recent literature demonstrates that in spite of Hicks's and Samuelson's attempts, hedonism-related concepts are still present. For instance, in an article which aims to explain why self-employment and income differ significantly by race, Bonjas and Bronars make a number of assumptions about the behaviour of agents. One of the most important of these is that agents maximize their utility (see Bonjas and Bronars, 1989, pp. 584-5). The same assumption is employed in an examination of private income transfers. In particular, it is assumed that parents maximize their utility when they transfer income to heirs. This assumption is made in a paper which attempts to examine the motives for private income transfers (see Cox, 1986, pp. 508-46). In the same spirit, Becker emphasizes the appropriateness of the 
assumption of utility maximization in the subfield of family economics (see Becker, 1988, p. 3).

Apart from the above, the standard theory of choice under uncertainty is based on the assumption that agents maximize expected utility. This can be seen in Alm's article, where the individual is assumed to maximize expected utility in a model which discusses the effect of tax uncertainty on individual decisions (Alm, 1988, pp. 237-45; also Binmore, 1989, p. 88). Moreover, this preoccupation with the idea of utility maximization has recently been stressed by theorists like K. Arrow and H. Simon. As mentioned above, the drive towards neutralization meant that only one assumption was necessary for the construction of choice theories: rationality. However, Arrow maintains that the apparently neutral assumption of rationality is almost always supplemented by assumptions of a different kind. The most common of these supplementary assumptions is utility maximization, to the point that "the concept of rationality in modern economics has been identified with it' (Arrow, 1987, pp. 202, 203). In order to support these arguments, Arrow gives an example which shows the importance of the assumption of utility maximization. He states that one can substitute utility maximization with habit formation. The consumer can still be rational and optimizing without aiming at utility maximization. As he writes: 'for a given price-income change, choose the bundle which satisfies the budget constraint and that requires the least change from the previous consumption bundle' (Arrow, 1987, p. 202). This approach is different from utility maximization, as can be seen from the fact that if prices and income return to their initial level after several alterations, the final bundle purchased will not be the same as the initial one (Arrow, 1987, p. 202).

H. Simon also stresses the preoccupation of many theorists with utility and utility maximization. He suggests that there is a bias towards the maximization of utility and proceeds to give an example of a decision situation where it is irrelevant but is still used because of the general attitude. He states that flood insurance is bought by persons who have experienced damaging floods or who are acquainted with persons who have had such experiences. As he declares: 'Utility maximization is neither a necessary nor a sufficient condition for deducing who will buy insurance-in this case, the process that puts the item on the decision agenda ... is the important thing (Simon, 1987, pp. 31, 32).

The preoccupation with utility maximization has to be connected with the idea of utility as a positive subjective sensation (satisfaction). Although a number of theorists maintain that it is a purely semantic concept, the majority conceive it as a sensation (see for instance Gravelle and Rees, 1981, p. 62). This can be seen from Becker's identification of the similarity of the utility function with Bentham's pleasure function (Becker, 1976, p. 137). One can also see further indications of this conception in recent papers like Myerson's and Bateman's, where a discussion of the connection of Benthamite utilitarianism with modern approaches can be found (see Myerson, 1981 and Bateman, 1988).

As an additional indication of the presence of hedonistic concepts in modern microeconomics, one can mention examples from the modern theory of choice under uncertainty. Furthermore, the conception of utility as a sensation can 
also be observed from the discussion. In particular, in their effort to account for some inconsistencies in the standard theory of choice under uncertainty, some theorists have developed the regret theory. The basic point of this theory is that people tend to compare their actual situations with the ones they would have been in, had they made different choices in the past (Loomes and Sugden, 1983, p. 428; Sugden, 1986). The subsequent analysis is conducted in terms of pleasurable or painful sensations.

If they realize that a different choice would have led to a better outcome, people may experience the painful sensation of regret; if the alternative would have led to a worse outcome, they may experience a pleasurable sensation we call rejoicing. (Loomes and Sugden, 1983, p. 428)

It is clear that this approach is not very far from hedonism, especially when we note that in a previous article the authors point out the similarity of their conception of utility with that of Benthamite pleasure (Loomes and Sugden, 1982 , p. 807). The specific reference to the psychological experience of pleasure, as well as the idea that agents are assumed to maximize expected modified utility, is another clear indication of the hedonistic connection. More importantly, the conduct of analysis on an explicitly psychological basis is in sharp contrast with the earlier attempts towards neutralization.

\section{VII}

\section{CONCLUSION}

The basic point of this paper has been to demonstrate the discrepancy between the developments in consumer theory of the last five decades and the way that this theory is presented by the majority of contemporary textbooks. In particular, it was pointed out that in contrast to modern choice theories which claim to be psychology-free, textbook consumer theory is characterized by a high level of hedonistic influence. Three possible explanations of this discrepancy were suggested: (1) pedagogic reasons; (2) Friedman's thesis; (3) implicit psychology in choice theories. My view is that the third explanation is the most plausible. This explanation of the textbooks' approach could be taken as a reflection and incorporation of the body of criticisms maintaining that modern choice theories implicitly assume the psychological concepts from which they claim to be independent. The fact that the textbook writers need to mention hedonistically based concepts in consumer theory implies that they are necessary for its comprehension. This is an indication of the implicit existence of such concepts in the theory itself.

This indication was reinforced by a discussion of some recent developments in the literature. It was observed that psychological concepts are still being employed; this has also been identified by a number of theorists, specifically by Arrow and Simon, who have emphasized the preoccupation of modern choice theories with utility maximization. Furthermore, the explicit presence of con- 
cepts like pleasurable and painful psychological sensations supports the above argument. Clearly, the implicit or (sometimes) explicit existence of hedonistic notions casts serious doubts on the alleged psychological neutrality of modern choice theories. This being so, it may be valuable to reopen the lines of communication between economists and psychologists to examine the empirical validity of the implicit hedonistic assumptions. ${ }^{2}$

\section{REFERENCES}

ALM, J. (1988). Uncertain tax policies, individual behavior and welfare. American Economic Review, 78, pp. 237-45.

ARON, R. (1967). Main Currents in Sociological Thought. London: Penguin.

ARROW, K. (1987). Rationality of self and others in an economic system. In Rational Choice, ed. R. Hogarth and M. Reder. Chicago: University of Chicago Press.

Arrow, K. and DebreU, G. (1954). Existence of an equilibrium for a competitive economy. Econometrica, 22, pp. 265-90.

BAtEMAN, B. (1988). G. E. Moore and J. M. Keynes: a missing chapter in the history of the expected utility model. American Economic Review, 78, pp. 1098-1106.

Becker, G. (1976). The Economic Approach to Human Behaviour. Chicago: University of Chicago Press.

BECKER, G. (1988). Family economics and macro behavior. American Economic Review, 78, pp. 1-13.

BegG, D., Fischer, S. and Dornbusch, R. (1984). Economics. Maidenhead: McGrawHill.

Bentham, J. (1823). An Introduction to the Principles of Morals and Legislation. Oxford: Clarendon Press.

BILAS, R. (1967). Microeconomic Theory. New York: McGraw-Hill.

BINMORE, K. (1989). Social contract I: Harsanyi and Rawls. Economic Journal, 99, pp. 84-102.

BirCH, T. (1985). Marshall and Keynes revisited. Journal of Economic Issues, 19, pp. 194-9.

BlaUG, M. (1978). Economic Theory in Retrospect. Cambridge: Cambridge University Press.

Blaug, M. (1980). The Methodology of Economics. Cambridge: Cambridge University Press.

BOLAND, L. (1981). On the futility of criticizing the neoclassical maximization hypothesis. American Economic Review, 71, pp. 1031-6.

Bonjas, G. and BRONARS, R. (1989). Consumer discrimination and self-employment. Journal of Political Economy, 97, pp. 581-605.

CAIRnCRoss, A. (1955), Introduction to Economics. London: Butterworth.

COATs, A. W. (1976). Economics and psychology: the death and resurrection of a research programme. In Method and Appraisal in Economics, ed. S. Latsis. Cambridge: Cambridge University Press.

Cox, D. (1986). Motives for private income transfers. Journal of Political Economy, 95 , pp. 508-46.

DebreU, G. (1959). The Theory of Value. New York: Wiley.

DIOGENES LAERTIUS (1975). The Lives of Philosophers. Athens: Papiros.

DRAKOPOULOS, S. (1989). The historical perspective of the problem of interpersonal comparisons of utilities. Journal of Economic Studies, 16, pp. 35-51.

Edgeworth, F. Y. (1881). Mathematical Psychics. London: Kegan Paul.

Ferguson, C. E. and Gould, J. P. (1975). Microeconomic Theory. Homewood, Ill.: Richard Irwin.

\footnotetext{
${ }^{2}$ For a discussion of the history of the communication between economics and psychology see Coats, 1976.
} 
Fisher, I. (1965). Mathematical Investigations in the Theory of Value and Price. New York: Augustus M. Kelley.

FrankenA, W. (1963). Ethics. Englewood Cliffs, NJ: Prentice-Hall.

FrIedMAN, L. (1985). Microeconomic Policy Analysis. New York: McGraw-Hill.

Friedman, M. (1953). Essays in Positive Economics, Chicago: University of Chicago Press.

GEORGESCU-RoEGEN, N. (1936). The pure theory of consumer's behaviour. Quarterly Journal of Economics, pp. 545-93.

Georgescu-Roegen, N. (1966). Analytical Economics. Cambridge, Mass.: Harvard University Press.

Georgescu-Roegen, N. (1976). Energy and Economic Myths. New York: Pergamon Press.

Gravelle, H. and ReEs, R. (1981). Microeconomics. London: Longman.

Graven, J. (1984). Introduction to Economics. Oxford: Basil Blackwell.

GREEN, J. (1976). Consumer Theory, London: Macmillan.

HEndERSon, J, and QuAndr, R. (1980). Microeconomic Theory. New York: McGrawHill.

Hicks, J. (1946). Value and Capital. Oxford: Clarendon Press.

Hicks, J. (1956). A Revision of Demand Theory. Oxford: Clarendon Press.

Hicks, J. and Allen, R. G. D. (1934). A reconsideration of the theory of value. Economica, 1, pp. 52-76.

HOUTHAKKER, H. (1950). Revealed preferences and the utility function. Economica, 17, pp. $159-74$.

JAFFE, W. (1977). The birth of Leon Walras's 'eléments'. History of Political Economy, 9, pp. 197-214.

JEvons, S. (1871). The Theory of Political Economy. London: Macmillan.

JOHNSON, W. (1913). The pure theory of utility curves. Economic Journal, 23, pp. $483-513$.

KeynES, J. M. (1973). The Collected Writings of J. M. Keynes, vol. X. London: Macmillan.

KoOpmans, T. (1957). Three Essays on the State of Economic Science. London: McGraw-Hill.

Koutsoyiannis, A. (1979). Modern Microeconomics. London: Macmillan.

KROEBER-RIEL, W. (1971). Constructs and empirical basis in theories of economic behaviour. Theory and Decision, 1, pp. 337-49.

LAIDLER, D. (1981). Introduction to Microeconomics. Oxford: Philip Allan.

LANCASTER, K. (1974). Introduction to Modern Microeconomics, Chicago: Rand McNally.

LIPSEY, R. (1984). An Introduction to Positive Economics (also 4th edn 1975; 5th edn 1979). London: Weidenfeld and Nicholson.

LOASBY, B. (1976). Choice, Complexity and Ignorance. Cambridge: Cambridge University Press.

LOASBY, B. (1978). Whatever happened to Marshall's theory of value? Scottish Journal of Political Economy, 25, pp. 1-12.

LOOMES, G. and SUGDEN, R. (1982). Regret theory: an alternative theory of rational choice under uncertainty. Economic Journal, 92, pp. 805-24.

LOOMES, G. and SUGDEN, R. (1983). A rationale for preference reversal. American Economic Review, 73, pp. 428-32.

MCCONNEll, C. (1975). Economics. New York: McGraw-Hill.

Marshall, A. (1961). Principles of Economics (9th edn). London: Macmillan.

Menger, C. (1950). Principles of Economics, trans. J. Dingwall and B. F. Hoselitg. Glencoe, Ill.: Free Press.

Menger, C. (1963). Principles of Economics and Sociology, trans. F. J. Nock. Urbana: University of Illinois Press.

Mill, J. S. (1979). Utilitarianism, ed. M. Warnock. Glasgow: Collins.

Miller, R. (1978). Intermediate Microeconomics. New York: McGraw-Hill.

Mishan, E. J. (1961). Theories of consumer behaviour: a cynical view. Economica, 28, pp. $1-11$.

MYERSON, R. (1981). Utilitarianism, egalitarianism, and the timing effect in social choice problems. Econometrica, 49, pp. 883-897. 
Pareto, V. (1971). Manual of Political Economy, trans. A. Schwier, London: Macmillan.

Robins, L. (1932). An Essay on the Nature and Significance of Economic Science. London: Macmillan.

Robsins, L. (1970). The Evolution of Modern Economic Theory, London: Macmillan.

Robinson, J. (1962). Economic Philosophy. London: Penguin.

Roll, E. (1961). A History of Economic Thought. London: Faber and Faber.

RotWEIN, E. (1959). On the methodology of positive economics. Quarterly Journal of Economics 73, pp. 554-575.

Samuelson, P. (1938). A note on the pure theory of consumer behaviour. Economica, $5, \mathrm{pp} .61-71$.

Samuelson, P. (1947). Foundations of Economic Analysis. Cambridge, Mass.: Harvard University Press.

SAmUELSON, P. (1950). The problem of integrability in utility theory. Economica, 17, pp. $355-85$.

Samuelson, P. (1963). Problems of methodology-Discussion. American Economic Review Papers and Proceedings, 53, pp. 231-236.

Samuelson, P. (1980). Economics (11th edn). London: McGraw-Hill.

Schumpeter, J. (1963). History of Economic Analysis. London: George Allen and Unwin.

SENIOR, W. N. (1850). Political Economy. London: J. S. Griffin.

Simon, H. (1987). Rationality in psychology and economics. In Rational Choice, ed. R. Hogarth and M. Reder. Chicago: University of Chicago Press.

SLUTSKY, E. (1915). On the theory of the budget of the consumer. Giornale degli Economisti.

SOLMON, L. (1976). Economics. Reading, Mass.: Addison-Wesley.

Stigler, G. J. (1966). The Theory of Price, New York: Macmillan.

Stonier, A. and Hague, D. (1980). A Textbook of Economic Theory. London: Longman.

SugdeN, R. (1986). New developments in the theory of choice under uncertainty. Bulletin of Economic Research, 38, pp. 1-24.

Veblen, T. (1972). Professor Clark's economics. In A Critique of Economic Theory, ed. E. K. Hunt and J. Schwartz. Harmondsworth: Penguin.

Walras, L. (1965). Elements of Pure Economics, trans. W. Jaffe. London: George Allen and Unwin.

WALSH, V. (1970). Introduction to Contemporary Microeconomics. New York: McGraw-Hill.

WhITTAKER, E. (1960). Schools and Streams of Economic Thought. Chicago: Rand McNally.

Watson, J. (1930). Behaviorism. Chicago: Chicago University Press.

WINTER, S. (1969). Concepts of rationality in behavioural theory. Institute of Public Policy Studies, University of Michigan.

Wong, S. (1978). The Foundations of Paul Samuelson's Revealed Preference Theory. London: Routledge and Kegan Paul.

Zeller, E. (1901). Outlines of the History of the Greek Philosophy. London: Longman. 